\title{
KOMPUTERISASI AKUNTANSI PENGGAJIAN KARYAWAN PADA PT. SUMMIT ADYAWINSA INDONESIA BERBASIS WEB
}

\author{
${ }^{1}$ Lela Komalasari, ${ }^{2}$ Indaryono \\ E-mail : ${ }^{1}$ lelakomalasari1201@gmail.com, ${ }^{2}$ indaryono@ dosen.rosma.ac.id
}

\begin{abstract}
Abstraksi
Proses penggajian karyawan PT Summit Adyawinsa Indonesia sudah menggunakan komputer namun masih belum terintegrasi karena masih menggunakan Micrososft Excel dalam perhitungan gaji. Proses penggajian ini belum memberikan hasil maksimal karena sering adanya kesalahan dalam penyajian data atau informasi. Oleh karena itu, perlu dibuat sebuah sistem penggajian karyawan berbasis komputer dan terintegrasi yang diharapkan dapat menyajikan informasi data gaji karyawan yang akurat.

Penyusunan sistem penggajian karyawan dimulai dengan poses perencanaan kebutuhan sistem dilanjutkan dengan analisa dan proses perancangan sistem yang didasarkan pada hasil analisa kebutuhan sistem. Tahap terakhir dari proses penyusunan sistem ini adalah implementasi perancanngan sistem menjadi seuah sistem yang baru.

Hasil dari penelitian ini didapatkan sebuah sistem penggajian karyawan berbasis komputer web yang menggunakan aplikasi Adobe Dreamweaver dengan My SqlServer sebagai databasenya. Hasil keluaran yang diperoleh dari sistem ini adalah data karyawan yang terkait dengan penggajian, rekap gaji, dan pembuatan slip gaji karyawan.

Dibuatnya sistem penggajian karyawan ini diharapkan dapat mempermudah untuk melakukan proses perhitungan gaji karyawan, terhindar dari kesalahan, dan dapat mengefektifkan waktu penginputan dan perhitungan penggajian.
\end{abstract}

Kata Kunci : Penggajian, My SqlServer, Adobe Dreamweaver

\begin{abstract}
Process payroll in PT Summit Adyawinsa Indonesia it has been used computer but still not integrated because they still use Micrososft Excel in calculating of salaries. The Payroll process is not giving maximum resuts because often errors in the presentment of data or information. Therefore, it should be made a payroll system based computer and integrated who are expected to present the employee salary data accurate information.

Preparation of employee payroll system begins with the planning process and proceed with the system requirements analysis and system design process that is based on the needs assesment. The last stage of the process of preparing this system is the implementation of system design into a new system.

The results of this study found an employee payroll system computer based web that uses the Adobe Dreamweaver app with My SqlServer as its database. The outputs obtained from this system is personal data related to the employee payroll, payroll recap, employee paychecks.

With be made a employee payroll system is expected to make it easier to perform calculations, avoid errors, can streamline payroll and payroll calculation time.
\end{abstract}

Keywords : Payroll, My SqlServer, Adobe Dreamweaver 


\section{Pendahuluan}

Perkembangan teknologi yang terus meningkat memiliki kemampuan dalam mengelola data-data dan informasi yang lebih akurat. Salah satu contoh bidang pekerjaan yang mengelola informasi misalnya dalam pencatatan dan perhitungan penggajian karyawan pada perusahaan. Untuk mempermudah dalam mengelola data-data dan informasi maka dibutuhkan sebuah sistem komputer yang terintegrasi guna mempermudah dalam pengolahan data gaji, perhitungan $\mathrm{PPh}$ pasal 21 , dan penyajian laporan keuangan.

PT. Summit Adyawinsa Indonesia merupakan perusahaan yang bergerak dibidang otomotif untuk kendaraan roda empat. Sumber daya manusia pada perusahaan ini terbagi 3, Karyawan tetap, Kontrak, dan Outsourcing. Sistem penggajian yang dilakukan masih menggunakan Microsoft Excel.

Penggunaan Microsoft Excel belum optimal dalam perhitungan gaji. Mengingat saat ini jumlah karyawan mencapai sekitar 496 orang dan tentunya semakin bertambah, tentu memiliki kelemahan dalam hal penginputan karyawan baru, absensi, jam lembur, perhitungan gaji serta pembuatan laporan penggajian dibutuhkan waktu yang cukup lama dan sering terjadi data yang dihasilkan kurang tepat, sehingga mengakibatkan adanya karyawan komplain atas gaji yang didapat kurang sesuai. Hambatan lainnya dipengaruhi oleh personel payroll yang hanya satu orang dalam mengelola penggajian. Perusahaan membutuhkan aplikasi komputer yang terintegrasi dan sistematis guna memberikan hasil informasi secara cepat, akurat dan efisien.

Berdasarkan permasalahan tersebut diatas, penulis tertarik untuk membuat rancangan komputerisasi akuntansi penggajian dengan menggunakan aplikasi Adobe Dreamweaver CS5 dengan database MySQL Server, dengan harapan dapat memberikan kemudahan dalam pengelolaan penggajian (payroll) terhadap PT. Summit
Adyawinsa Indonesia dalam hal ini penulis menjadikan sebagai suatu bahasan dengan judul "Komputerisasi Akuntansi Penggajian Karyawan pada PT Summit Adyawinsa Indonesia Berbasis Web".

\section{Tinjauan Pustaka}

\section{Pengertian Sistem}

Menurut Yakub (2012:1), "Sistem adalah sekelompok elemen-elemen yang terintegrasi dengan tujuan yang sama untuk mencapai tujuan. Sistem juga merupakan suatu jaringan kerja dari prosedur-prosedur yang saling berhubungan, terkumpul bersamasama untuk melakukan suatu kegiatan atau tujuan tertentu".

\section{Pengertian Informasi}

Menurut Bambang Hartono (2011:66), "Informasi merupakan data yang telah diolah sehingga menjadi suatu bentuk yang penting yang berguna bagi penerimanya dan mempunyai kegunaan sebagai dasar dalam pengambilan keputusan yang dapat dirasakan akibatnya secara langsung atau secara tidak langsung dimasa yang akan datang".

$$
\text { Menurut Sutarman (2012:14), }
$$

"Informasi adalah sekumpulan fakta (data) yang diorganisasikan dengan cara tertentu sehingga mereka mempunyai arti bagi si penerima".

\section{Pengertian Sistem Informasi}

Menurut Anastasia Diana dan Lilis Setiawati (2011:4), "Sistem informasi merupakan sistem yang dibuat oleh manusia yang biasanya dari sekumpulan komponen baik manual ataupun berbasis komputer yang terintegrasi untuk mengumpulkan, menyimpan dan mengelola data serta menyediakan informasi kepada pihak-pihak yang berkepentingan sebagai pemakai informasi tersebut".

\section{Pengertian Sistem Informasi Akuntansi} Menurut Krismiaji (2015:4), "Sistem Informasi Akuntansi adalah sebuah sistem yang memproses data dan transaksi guna menghasilkan informasi yang bermanfaat 
untuk merencanakan, mengendalikan, dan mengoperasikan bisnis".

\section{Pengertian Bagan Alir (Flowchart)}

Menurut Krismiaji (2015:69), "Bagan alir merupakan teknik analitis yang digunakan untuk menjelaskan aspek-aspek sistem informasi secara jelas, tepat, dan logis. Bagan alir menggunakan serangkaian simbol standar untuk menguraikan prosedur pengolahan transaksi yang digunakan oleh sebuah perusahaan, sekaligus menguraikan aliran data dalam sebuah sistem".

\section{Pengertian DFD (Data Flow Diagram)}

Menurut Lilis Puspitawati dan Sri Dewi Anggadini (2014:109), Data Flow Diagram menggambarkan sistem sebagai jaringan kerja antar fungsi yang berhubungan satu sama lain melalui aliran dan penyimpanan datanya.

\section{Pengertian ERD (Entity Relationship Diagram)}

Menurut Lilis Puspitawati dan Sri Dewi Anggadini (2014:109), "ERD merupakan suatu peralatan pembuatan model data yang paling fleksibel, dapat diadaptasi untuk berbagai pendekatan yang mungkin diikuti perusahaan dalam pengembangan sistem".

Menurut Edhy Sutanta (2011:92), ERD tersusun atas tiga komponen, antara lain entitas (entity), atribut (attribute), dan kerelasian antar entitas (relationship).

\section{Pengertian Kamus Data}

Menurut Yakub (2012:125), "Kamus data adalah suatu daftar data elemen yang terorganisir dengan definisi yang tetap dan sesuai dengan sistem, sehingga user dan analis sistem mempunyai pengertian yang sama tentang input, output, dan komponen data store. Kamus data ini sangat membantu analis sistem dalam mendefinisikan data yang mengalir di dalam sistem, sehingg pendefinisian data itu dapat dilakukan dengan lengkap dan terstruktur.Pembentukan kamus data dilaksanakan dalam tahap analis dan perancangan suatu sistem".

\section{SDLC (System Development Life Cycle)}

Menurut Bambang Hartono (2011:129), "SDLC adalah proses yang digunakan oleh analis sistem untuk mengembangkan sistem informasi, termasuk persyaratan, validasi, pelatihan dan pengguna (stakeholder) kepemilikan. Setiap SDLC harus menghasilkan sistem berkualitas tinggi yang memenuhi atau melampaui harapan pelanggan, mencapai penyelesaian dalam waktu dan perkiraan biaya, bekerja secara efektif dan efisien di saat ini dan direncanakan teknologi informasi infrastuktur dan murah untuk mempertahankan biaya efektif".

\section{Pengertian SDLC Waterfall}

Menurut Rosa AS \& M Shalahuddin (2014:28-29), Model SDLC air terjun (waterfall) sering juga disebut model sekuensial linier (Sequential liniear) atau alur hidup klasik (Classic life cycle). Model air terjun menyediakan pendekatan alur hidup perangkat lunak secara sekuensial atau terurut dimulai dari analisis, desain, pengodean, pengujian, dan tahap pendukung (support).

\section{Pengertian Website}

Menurut Abdul Kadir (2014:186), dalam membuat suatu pemrograman, biasanya orang-orang tertentu seperti programmer menggunakan pemrograman berbasis web atau berbasis desktop. Web browser atau disebut browser (peramban) saja adalah perangkat lunak yang berguna untuk mengakses informasi web ataupun untuk melakukan transaksi via web.

\section{PHP (Pre Hyper Text)}

Menurut Anton Subagia (2016:3), "PHP merupakan kependekan dari Personal Home Page (situs personal) sebuah pemograman yang berjalan dalam sebuah web server (server side)". PHP diciptakan oleh programmer Unis dan Perl bernama Rasmus Lerdoft pada bulan Agustus-September 1994.

\section{Adobe Dreamweaver \\ Menurut Sibero (2010:384), "Dreamweaver merupakan sebuah produk web developer yang dikembangkan oleh}


Adobe Sistems Inc., sebelumnya produk Dreamweaver dikembangkan oleh Macromedia Inc, yang kemudian sampai saat ini perkembangannya diteruskan oleh Adobe Sistems Inc. Dreamweaver dikembangkan dan dirilis dengan kode nama Creative Suit (CS). Ruang kerja Dreamweaver terdiri dari Welcome screen,Menu,Insert Bar,Document window,CSS Panel, Aplication Panel, Tog Inspector".

\section{Pengertian XAMPP}

Menurut Riyanto (2010:10), "XAMPP berperan sebagai server web pada komputer. XAMPP juga dapat disebut sebuah Panel Server Virtual yang dapat membantu untuk melakukan preview, sehingga dapat memodifikasi website tanpa harus online atau terakses dengan internet.

XAMPP merupakan akronim dari $\mathrm{X}$ (Artinya lintasan flatform), Appache HTTP Server, $M y, S Q L, P H P$, dan Perl. Program ini dikeluarkan sebagai free web-server yang mampu digunakan untuk dinamis web. XAMPP dapat digunakan pada Microsoft Windows, Linux, dan Operating System yang lainnya.

\section{Pengertian MySql}

Menurut Budi Raharjo (2011:21), "MySQL merupakan server database yang mengelola database dengan cepat menampung dalam jumlah sangat besar dan dapat diakses oleh banyak user. MySQL merupakan alat bantu untuk manipulasi basis data, sehingga basis data dapat dengan mudah diisi, diambil, disusun, dan diubah datanya. Server MySQL pun dapat mengatur kontrol ases dari data, sehingga beberapa pengguna dapat sekaligus bekerja pada waktu yang bersamaan".

\section{Pengertian Penggajian}

Menurut Mardi (2011:107), “Gaji adalah sebuah bentuk pembayaran atau sebuah hak yang diberikan oleh sebuah perusahaan atau instansi kepada pegawai tetap".

\section{Pengertian PPh Pasal 21}

Menurut Waluyo (2011:201), "Pajak penghasilan pasal 21 merupakan pajak penghasilan yang dikenakan atas penghasilan berupa gaji, upah, honorium, tunjangan, dan pembayaran lain dengan nama apapun sehubungan dengan pekerjaan, jasa, atau kegiatan yang dilakukan oleh wajib pajak orang pribadi dalam negeri".

\section{UU Ketenagakerjaan}

Dalam Undang-Undang Nomor 13 tahun 2003 tentang ketenagakerjaan Bab 1 pasal 1 point 1 , "Upah adalah hak pekerja/buruh yang diterima dan dinyatakan dalam bentuk uang sebagai imbalan dari pengusaha atau pemberi kerja kepada pekerja/buruh yang ditetapkan dan dibayarkan menurut suatu perjanjian kerja, kesepakatan, atau peraturan perundang-undangan, termasuk tunjangan bagi pekerja/buruh dan keluarganya atas suatu pekerjaan dan/atau jasa yang telah atau akan dilakukan".

\section{Tarif PTKP Tahun 2016}

Tarif PTKP terbaru atau pun tarif PTKP 2017 masih sama dengan tarif PTKP 2016 yang masih mengacu pada Peraturan Direktur Jenderal Pajak No. PER16/PJ/2016, Peraturan Menteri Keuangan yaitu PMK No. 101/PMK.010/2016 dan PMK No. 102/PMK.010/2016 pada tanggal 22 Juni 2016 dan berlaku sejak tanggal 1 Januari 2016. Berikut ini rincian Penghasilan Tidak Kena Pajak terbaru.

Tarif PTKP terbaru selama setahun untuk perhitungan PPh Pasal 21 berdasarkan PMK No. 101/PMK.010/2016 adalah sebagai berikut:

- Rp 54.000.000,- untuk diri Wajib Pajak orang pribadi

- Rp 4.500.000,- tambahan untuk Wajib Pajak yang kawin

- Rp 54.000.000,- untuk istri yang penghasilannya digabung dengan penghasilan suami.

- Rp 4.500.000,- tambahan untuk setiap anggota keluarga sedarah dan keluarga semenda dalam garis keturunan lurus serta 
anak angkat yang menjadi tanggungan sepenuhnya, paling banyak 3 rang untuk setiap keluarga.

\section{Metode Penelitian}

Metode penelitian yang digunakan dalam pembuatan aplikasi ini adalah SDLC (Systems Development Life Cycle) dengan model waterfall. Model SDLC air terjun (waterfall) sering juga disebut model sekuensial linier (Sequential liniear) atau alur hidup klasik (Classic life cycle). Model air terjun menyediakan pendekatan alur hidup perangkat lunak secara sekuensial atau terurut dimulai dari analisis, desain, pengodean, pengujian.

Berikut adalah gambar model waterfall.

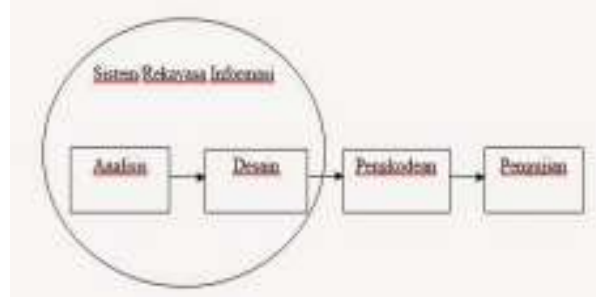

Gambar 1. ilustrasi model waterfall

Sumber : Rosa dan M.S (2014:29)

1. Analisis Kebutuhan Perangkat Lunak.

Proses pengumpulan kebutuhan dilakukan secara intensif untuk menspesifikasikan kebutuhan perangkat lunak agar dapat dipahami perangkat lunak seperti apa yang dibutuhkan oleh user. Spesifikasi kebutuhan perangkat lunak pada tahap ini perlu untuk didokumentasikan. Dalam hal ini penulis menggunakan teknik pengumpulan data sebagai berikut :

a. Observasi (Pengamatan)

Yaitu dengan melakukan pengamatan secara langsung dengan objek yang diteliti. Adapun data yang diperlukan tersebut berupa gambaran umum mengenai PT Summit Adyawinsa Indonesia khususnya tentang Human Resource Development (HRD) Payroll.

b. Wawancara (Interview)

Yaitu mengadakan tatap muka secara langsung salah satunya dengan Bapak
Ary Kristiyanto sebagai pihak bagian payroll serta dengan berbagai pihak lain yang terkait di dalam mengumpulkan data-data perusahaan yang penulis perlukan sebagai bahan pembahasan proposal Penelitian ini.

c. Studi Kepustakaan (Library Research) Yaitu penelitian yang dilakukan di perpustakaan untuk mengumpulkan data-data sekunder yang bersumber pada buku-buku dan dokumen yang berkaitan dengan masalah yang diteliti untuk memperoleh suatu landasan teori.

\section{Desain}

Penyusunan dan perancangan desain perangkat lunak sistem penggajian ini, metode perancangan yang digunakan penulis mencakup DFD (Data Flow Diagram), Flowchart, Kamus data, ERD (Entity Relationship Diagram), Pembuatan bagan terstruktur dan rancangan pemasukan \& keluaran.

\section{Pengkodean}

Menurut sumber buku Rekayasa Perangkat Lunak Terstruktur dan Berorientasi Objek (Rosa AS \& M.Shalahuddin,2014:29), desain harus ditranslasikan ke dalam program perangkat lunak. Hasil dari tahap ini adalah program komputer sesuai dengan desain yang telah dibuat pada tahap desain. Dalam hal ini digunakan bahasa pemrograman $W E B$ dengan aplikasi Adobe Dreamweaver CS5 dan MySQL Server sebagai databasenya.

\section{Pengujian}

Tahap ini proses akan menguji kode program yang telah dibuat dengan memfokuskan pada bagaian perangkat lunak. Hal ini dilakukan untuk meminimalisir kesalahan (error) dan memastikan hasil keluaran yang dihasilkan sesuai dengan yang diinginkan.

\section{Hasil Penelitian dan Pembahasan}

Hasil Temuan/Permasalahan yang ada pada sistem penggajian karyawan PT. Summit Adyawinsa Indonesia belum adanya program yang terintegrasi, masih menggunakan 
Microsoft Excell karena itu sering muncul kesalahan dalam penginputan data, human error atau program error misalnya kesalahan dalam rumus/formula ketika menginput absensi karyawan, lembur karyawan, yang disebabkan semakin banyak atau bertambahnya karyawan pada PT Summit Adyawinsa Indonesia dimana sistem yang digunakan masih dengan Microsoft Excel sehingga perhitungan penggajian kurang akurat dan sering terjadi kesalahan. Selain itu ditemukan permasalahan pada personel payroll yang hanya satu orang, menjadikan proses pekerjaan payroll mengalami adanya hambatan.

$\underline{\text { Solusi Pemecahan Masalah }}$

Berdasarkan analisa penulis dengan melihat permasalahan yang ada pada sistem penggajian karyawan PT. Summit Adyawinsa Indonesia, penulis mempunyai solusi agar PT. Summit Adyawinsa Indonesia menggunakan sistem penggajian yang terkomputerisasi dengan menggunakan aplikasi Adobe Dreamweaver CS5 dengan database menggunakan My SQL Server sehingga database penggajian akan terintegrasi, tersimpan dengan baik dan mengurangi kesalahan dalam penginputan data.

Selain itu untuk menangani hambatan yang terjadi dalam pekerjaan bagian payroll, maka dari itu pihak Human Resource Development (HRD) perlu menambahkan personel untuk membantu pekerjaan pada bagian payroll.

\section{Sistem Usulan}

Berdasarkan identifikasi masalah di atas, maka penulis membangun sebuah sistem usulan dengan sebagai berikut :

\section{a) Usulan Prosedur yang Baru}

Adapun usulan prosedur yang baru dalam sistem penggajian karyawan adalah sebagai berikut :

1) Karyawan

a. Karyawan melakukan absen dengan Finger Print.

b. Karyawan mengajukan Surat Perintah Lembur (SPL). c. Karyawan menerima gaji melaui transfer bank dan menerima slip gaji.

2) Administrasi

a. Menerima absensi karyawan dengan mendownload dari finger printi dan menerima Surat Perintah Lembur (SPL) yang telah diajukan karyawan.

b. Mengecek ulang absen dan SPL sesuai dengan ketentuan jam hadir.

c. Menginput ketidakhadiran berupa surat Izin, Surat Dokter dan Cuti karyawan.

d. Menginput absen, ketidakhadiran dan input SPL Membuat rekap absensi dan rekap lembur karyawan untuk di berikan ke bagian payroll.

3) Payroll
a. Menerima rekap absensi dan rekap lembur karyawan dari bagian admin
b. Mengecek ulang rekapan tersebut
c. Menghitung gaji karyawan sesuai dengan Data Absensi Karyawan (DAK), Data Lembur Karyawan (DLK), BPJS, pemotongan pajak $\mathrm{PPh}$ 21 , beserta potongan lainnya.
d. Membuat rekap gaji 2 (dua) rangkap.
e. Membuat Slip Gaji.

4) Bank
a. Menerima rekap gaji yang sudah di validasi
b. Menerima cek/giro
c. Mentransfer gaji ke rekening masing-masing karyawan.


b) Flowmap Usulan

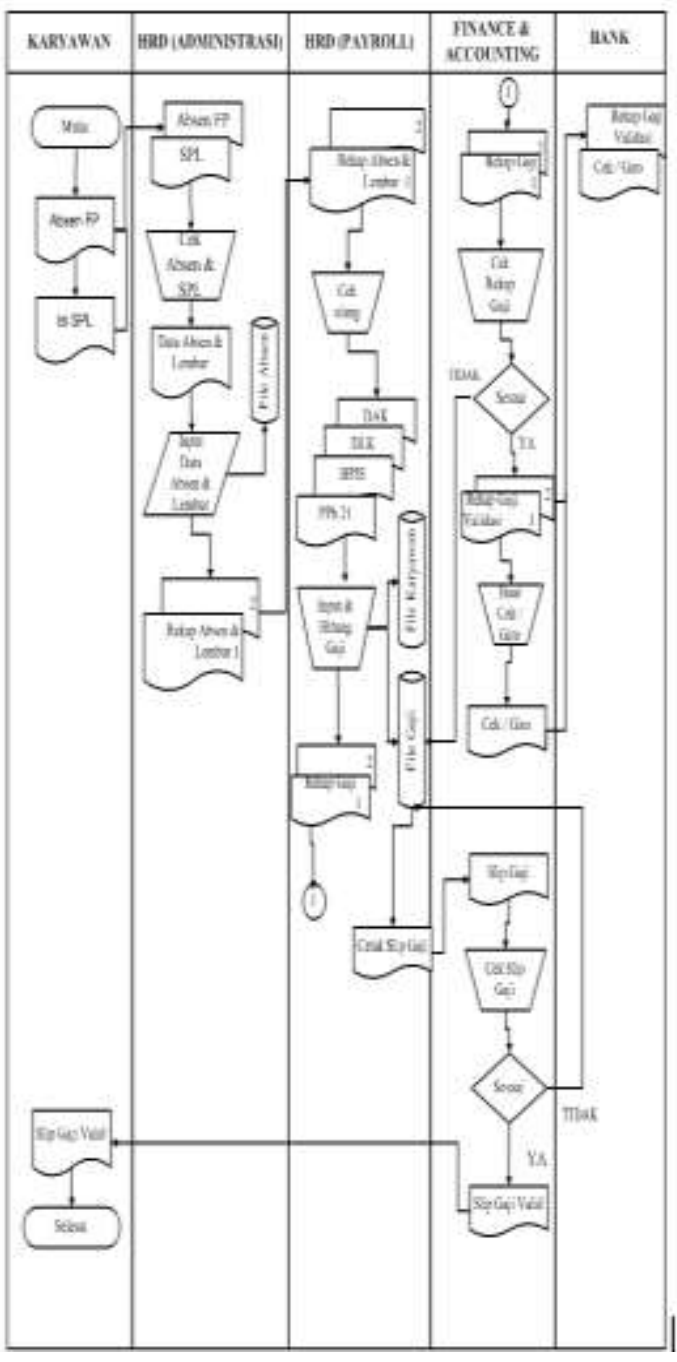

Gambar 2. Flowmap Usulan

\section{c) Diagram Konteks}

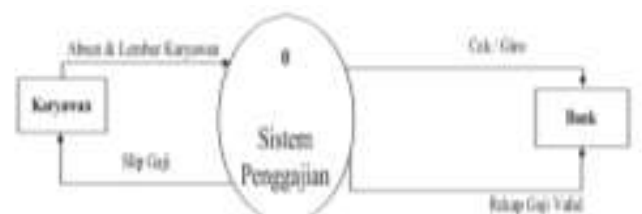

Gambar 3. Diagram Konteks

\section{d) Diagram Nol}

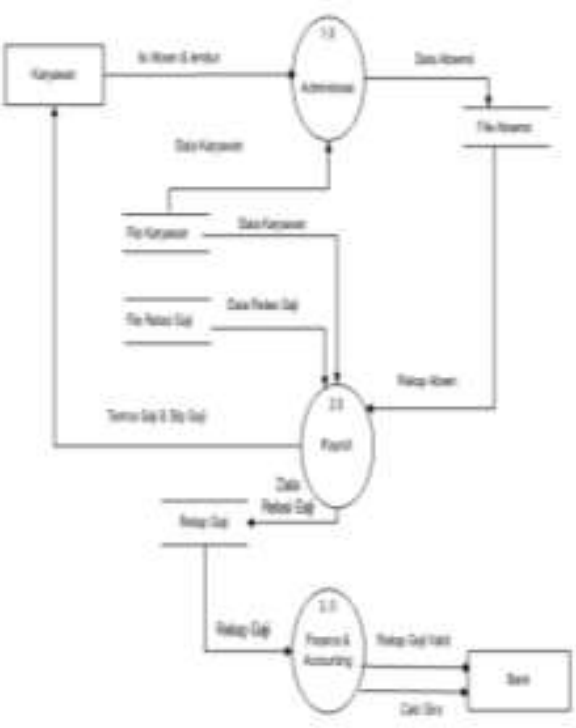

Gambar 4. Diagram Nol

e) ERD

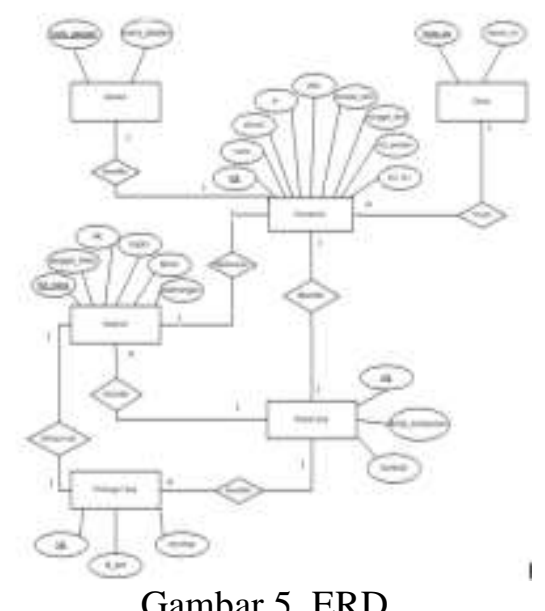

Gambar 5. ERD

\section{Implementasi Sistem}

1. Tampilan Front End

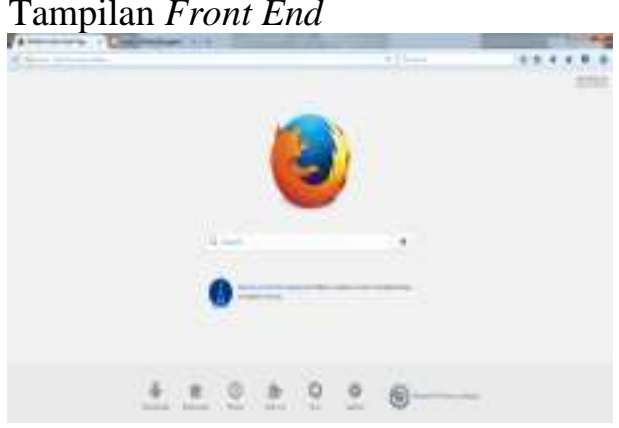

Gambar 6. Tampilan Front End 
Keterangan :

Gambar 6, untuk dapat mengakses aplikasi ini diperlukan suatu web browser, seperti Internet Explorer, Mozilla Firefox atau browser lainnya. Cara mengoperasikan aplikasi berbasis web untuk front end dengan web browser Mozilla Firefox dengan cara mengetikan $U R L$-nya maka langsung muncul halaman login user.

\section{Tampilan Form Login}

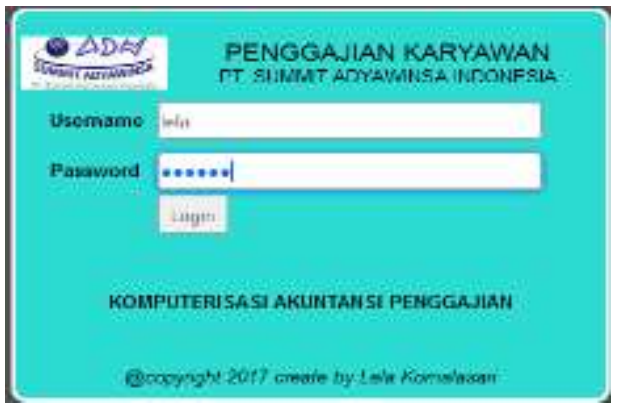

Gambar 7. Form Login

\section{Keterangan :}

Gambar 7 tampilan Form Login merupakan halaman hak akses untuk user agar dapat masuk pada Form Utama maka harus mengisi username dan password.

\section{Tampilan Form Menu Utama}

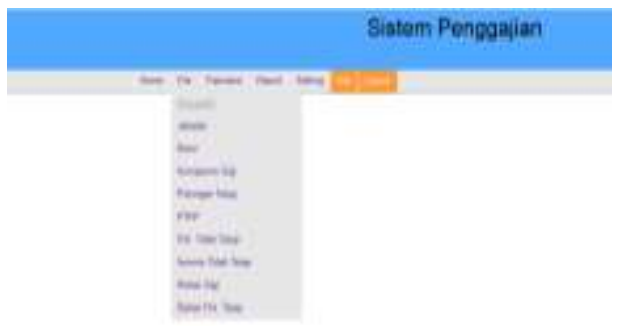

Gambar 8. Form Menu Utama

\section{Keterangan :}

Tampilan Form Menu Utama merupakan Menu untuk menampilkan semua menu yang muncul pada halaman utama sistem penggajian dimulai dari menu home, file, transaksi, report, setting dan logout.
4. Tampilan Form Input Karyawan

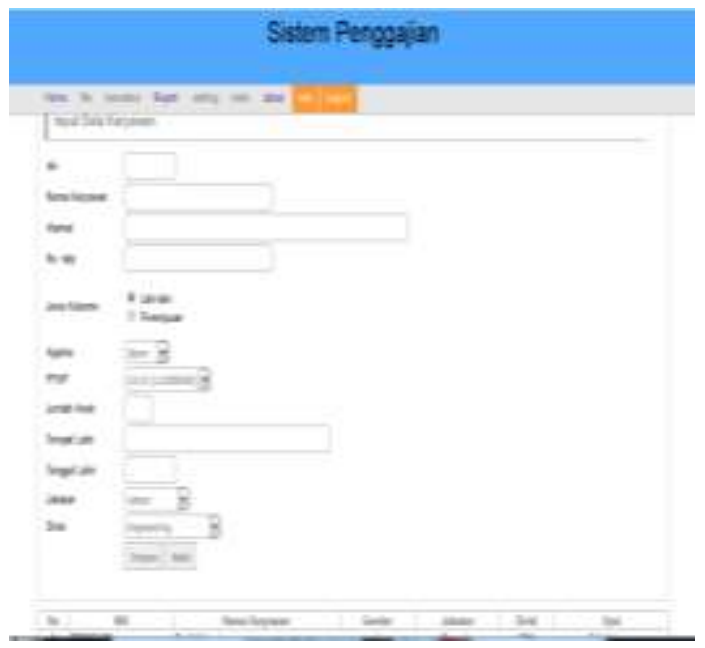

Gambar 9. Form Input Karyawan

Keterangan :

Gambar 9 Form Input Data Karyawan merupakan form untuk menambahkan, mengubah, menampilkan data karyawan.

5. Tampilan Form Input Jabatan

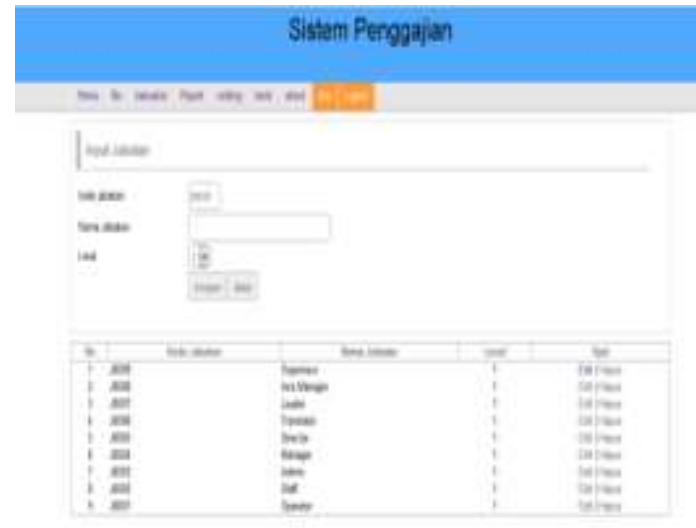

Gambar 10. Form Input Jabatan

Keterangan :

Gambar 10 Form Input Jabatan merupakan form untuk menginput data jabatan karyawan. 
6. Tampilan Form Input Divisi

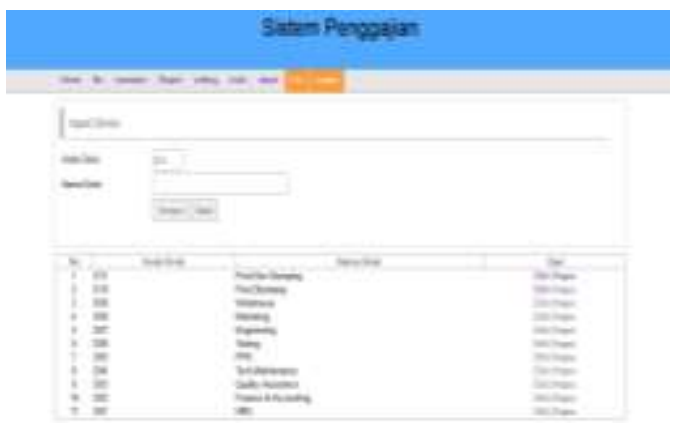

Gambar 11. Form Input Divisi

Keterangan :

Gambar 11 Form Input Divisi merupakan form untuk menginput data divisi atau departmen yang ada di perusahaan.

7. Tampilan Form Input Komponen Gaji

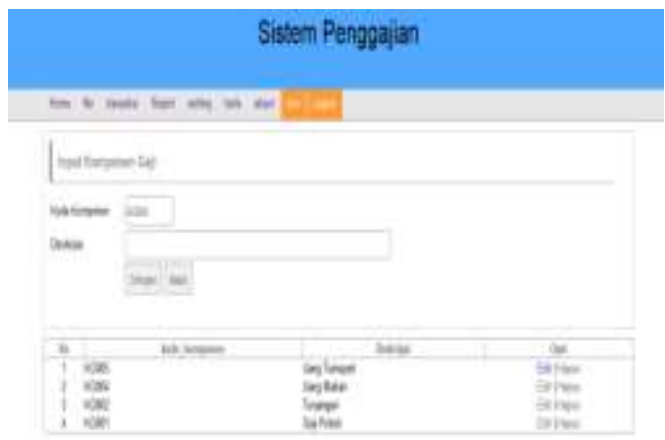

Gambar 12. Form Input Komponen Gaji

Keterangan :

Gambar 12 Form Input Komponen Gaji merupakan form untuk menginput komponen gaji karyawan.

8. Tampilan Form Input Potongan Gaji

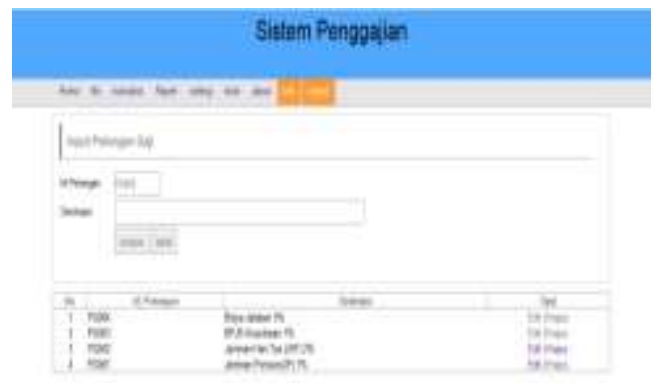

Gambar 13. Form Input Potongan gaji
Keterangan :

Gambar 13 Form Input Potongan Gaji merupakan form untuk menginput potonganpotongan gaji karyawan yang sifatnya potongan tetap.

\section{Tampilan Form Input PTKP}

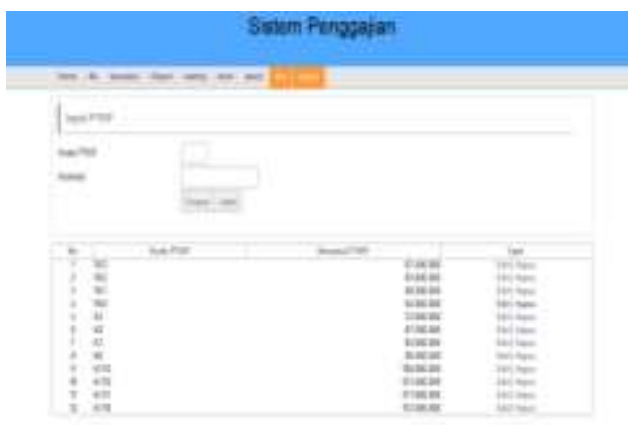

Gambar 14. Form Input PTKP

Keterangan :

Gambar 14 Form Input PTKP merupakan form untuk menginput status PTKP karyawan beserta nominalnya.

10.Tampilan Form Input Potongan Tidak Tetap

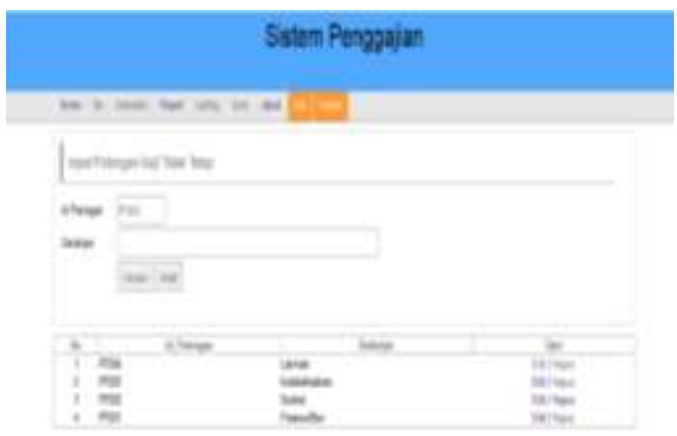

Gambar 15. Form Potongan Tidak Tetap

Keterangan :

Gambar 15 Form Input Potongan Tidak Tetap merupakan form untuk menginput potonganpotongan gaji karyawan yang sifatnya tidak tetap. 


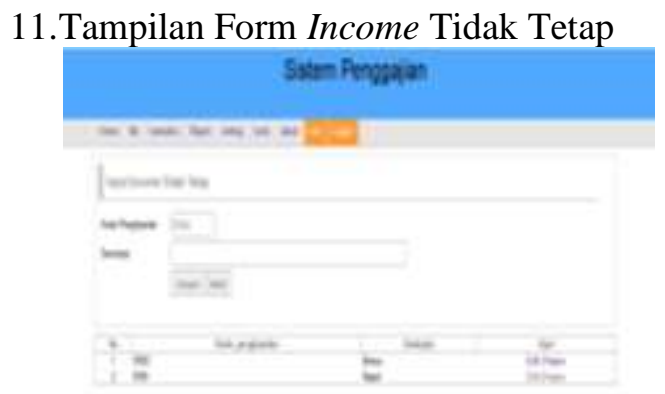

Gambar 16. Form Income Tidak Tetap

Keterangan :

Gambar 16 Form Input Income Tidak Tetap merupakan form untuk menginput pendapatan yang sifatnya tidak tetap.

\section{Tampilan Form Relasi Gaji}

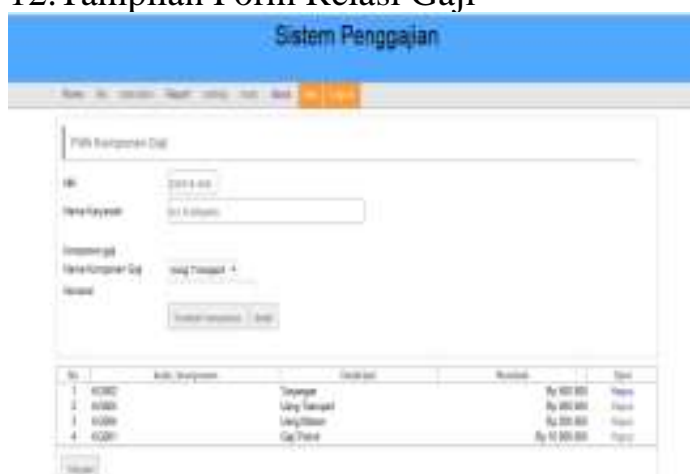

Gambar 17. Form Relasi Gaji

Keterangan :

Gambar 17 Form Relasi Gaji merupakan form untuk merelasikan gaji karyawan yang sifatnya tetap setiap periode dimulai dari mencari data nama karyawan. Form ini di relasikan dari file data karyawan dengan file komponen gaji karyawan.

\section{Tampilan Form Potongan Tetap}

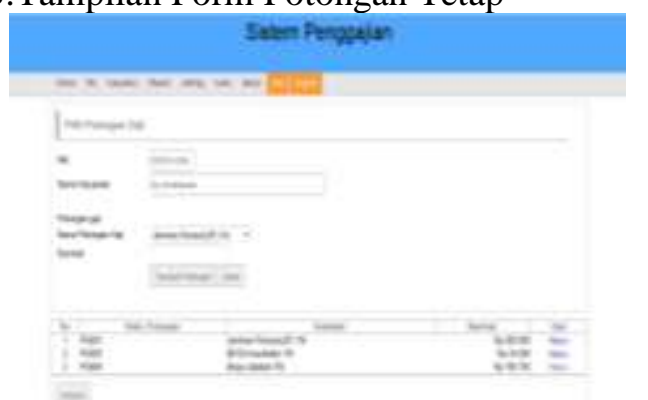

Gambar 18 Form Potongan Tetap
Keterangan :

Gambar 18 Form Relasi potongan tetap merupakan form untuk merelasikan potongan gaji karyawan yang sifatnya tetap setiap periode dimulai dari mencari data nama karyawan. Form ini di relasikan dari file data karyawan dengan file potongan tetap.

\section{Form Transaksi Absensi}

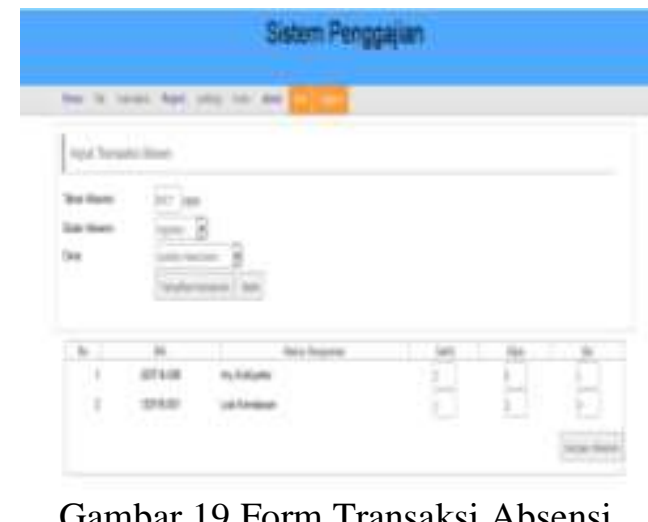

Keterangan :

Gambar 19 Form Input Transaksi Absensi merupakan form untuk menginput rekap absensi karyawan.

\section{Form Transaksi Lembur}

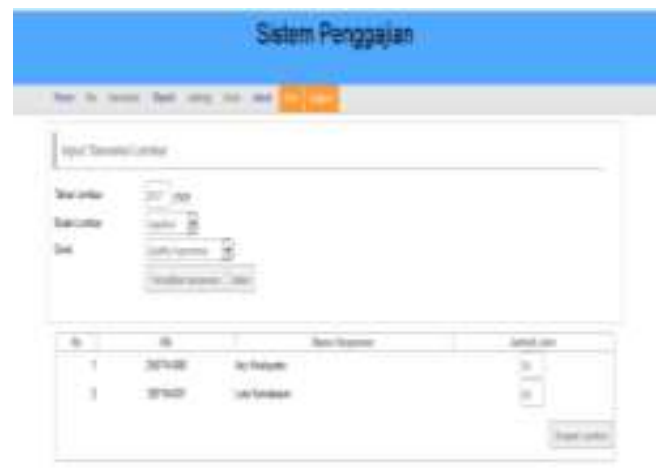

Gambar 20. Form Transaksi Lembur

Keterangan :

Gambar 20 Form Input Transaksi Lembur merupakan form untuk menginput jumlah jam pada rekap lembur karyawan. 


\section{Form Relasi Potongan Tidak Tetap}

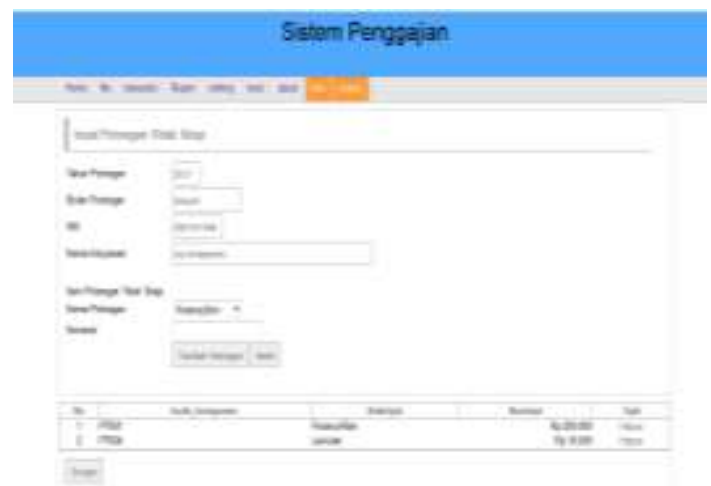

Gambar 21. Form Relasi Potongan Tidak Tetap

Keterangan :

Gambar 21 Form Relasi Potongan Tidak Tetap merupakan form untuk merelasikan potongan gaji karyawan yang sifatnya tidak tetap setiap periode. Form ini di relasikan dari file data karyawan dengan file potongan tidak tetap.

\section{Form Penghasilan Tidak Tetap}

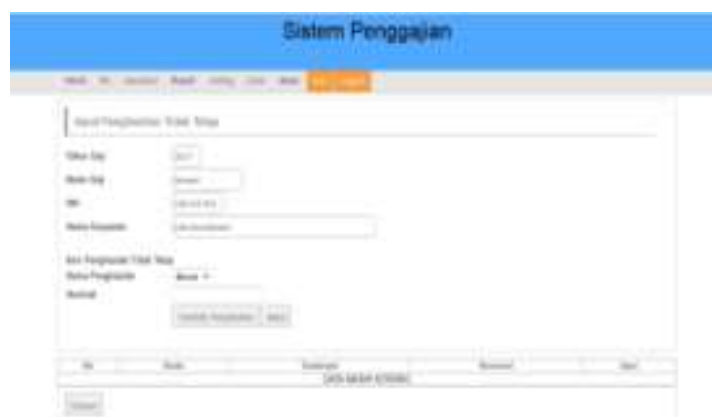

Gambar 22. Form Penghasilan Tidak Tetap

Keterangan :

Gambar 22 Form Penghasilan Tidak Tetap merupakan form untuk merelasikan penghasilan yang sifatnya tidak tetap setiap periode. Form ini di relasikan dari file data karyawan dengan file Income tidak tetap seperti bonus atau rapel.
18. Form Input Penggajian

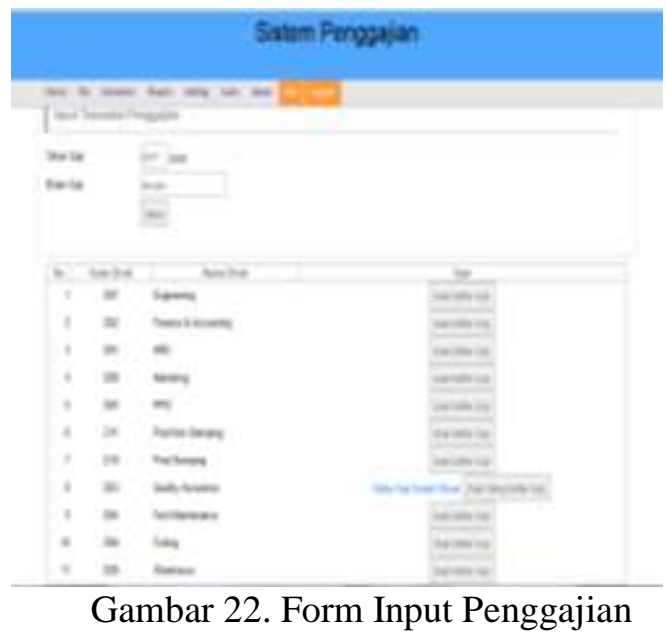

Keterangan :

Gambar 22 Form Input Penggajian merupakan form untuk merelasikan gaji karyawan berserta potongan-potongan setiap periode secara otomatis. Pada gambar 4.8 tersedia tombol Buat Daftar Gaji berfungsi untuk menampilkan data gaji berupa rekap gaji

\section{Tampilan Output Slip Gaji}

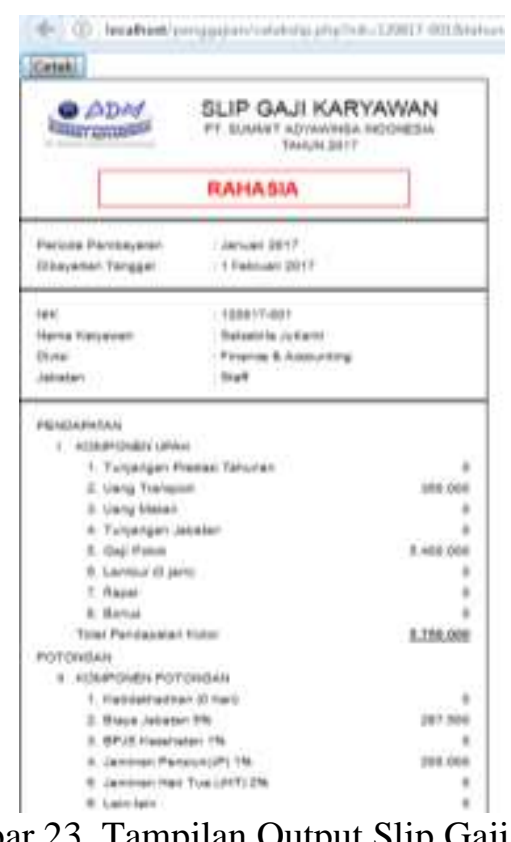

Gambar 23. Tampilan Output Slip Gaji 


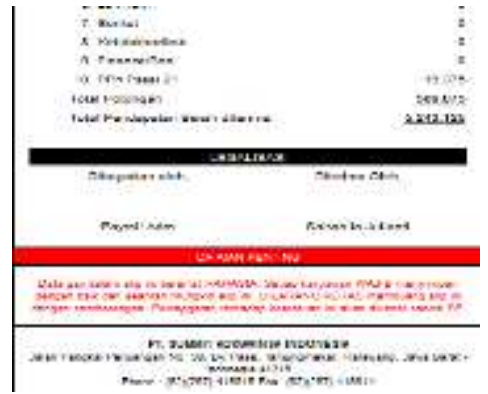

Gambar 23. Tampilan Output Slip Gaji (lanjutan)

20. Tampilan Output Rekap Gaji

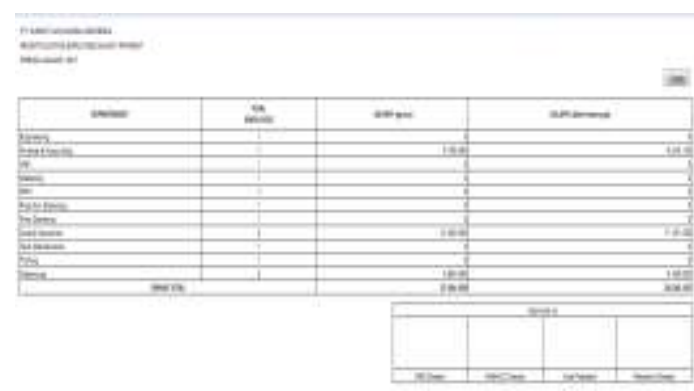

\section{Kesimpulan dan Saran}

\section{Kesimpulan}

Berdasarkan analisis dan pembahasan yang telah diuraikan pada bab-bab sebelumnya hasil dari laporan penelitian dengan judul Komputerisasi Akuntansi Penggajian Karyawan Pada PT Summit Adyawinsa Indonesia Berbasis Web, maka dapat diambil beberapa kesimpulan sebagai berikut :

a) Pada sistem penggajian karyawan berbasis web ini, permasalahan mengenai pengelolaan penggajian selama ini masih menggunakan microsoft excel yang belum optimal dengan adanya rancangan aplikasi penggajian berbasis web ini diharapkan memudahkan dalam menangani pengelolaan penggajian dan meminimalisir permasalahan yang sering terjadi pada penggajian.

b) Rancangan, pembuatan dan penyajian informasi penggajian karyawan berbasis web ini memiliki fasilitas-fasilitas yang dapat membantu dalam penginputan, perhitungan pajak PPh 21 karyawan dan perhitungan penggajian secara cepat serta memudahkan dalam pembuatan laporanlaporan mengenai penggajian.

c) Dengan dirancangnya sistem ini, diharapkan dapat mempermudah tugas dari staff HRD Payroll dalam mengelola gaji karyawan.

\section{Saran}

Hasil pengamatan dan analisa selama melakukan pengumpulan data dibagian penggajian pada PT Summit Adyawinsa Indonesia adalah sebagai berikut :

a) Sebelum menerapkan sistem penggajian karyawan berbasis web pada PT Summit Adyawinsa Indonesia ini perlu melakukan pelatihan terhadap karyawan yang akan mengoperasikan sistem penggajian ini.

b) Sistem harus dikembangkan lebih lanjut dengan tujuan meminimalisir terjadinya kesalahan ketika memproses gaji karyawan, yaitu dengan memaksimalkan sintaks dan tampilan massage box sebagai peringatan terjadinya kesalahan pada saat penginputan.

c) Back up data harus dilakukan secara berkala untuk menghindari hilangnya data jika terjadi kerusakan pada komputer sehingga data-data yang ada akan tetap terjaga.

\section{Daftar Pustaka}

Al-Bahra. (2013). Analisis dan Desain Sistem Informasi. Yogyakarta: Graha Ilmu.

Arief, M.Rudianto (2011). Pemrograman Web Dinamis Menggunakan PHP dan $M y S Q L$. Yogyakarta: CV.Andi Offset.

Dwi, Siska. (2014). Sistem Informasi Penggajian pada CV.Blumbung Sejati dengan berbasis Web. Journal Speed, Volume 6 Nomor 3, ISSN : 1979-9330.

Diana, Anastasia dan Lilis Puspitawati. (2011). Sistem Informasi Akuntansi, 
Perancangan,Proses dan Penerapan Edisi 1. Yogyakarta: Penerbit Andi.

Fathansyah. (2012). Basis Data. Bandung: Informatika.

Hartono, Bambang. (2011). Sistem Informasi Manajemen Berbasis Komputer. Jakarta: Rineka Cipta.

Jusup Al-Haryono. (2011). Dasar-dasar Akuntansi jilid satu edisi 7. Yogyakarta: Graha Ilmu

Kadir, Abdul. (2014). Pengenalan Sistem Informasi Edisi Revisi. Yogyakarta: Andi.

K. Taupik, Opik, Mohammad Irfan, dan Ai Nurfianti. (2013). Pembuatan Aplikasi Anbiyapedia Ensiklopedi Muslim Anak Berbasis Web. ISSN 19798911 No. 7 Vol. 1. Halaman 33-52

Krismiaji. (2015). Sistem Informasi Akuntansi. Yogyakarta: UPP STIM YKPN.

Kyky, Iwan. (2014). Sistem Informasi Pemotongan $\mathrm{PPh} 21$ atas Gaji Karyawan PT.Rajawali Tehnik dengan menggunakan Visual Basic 05. Journal Computech \& Bisnis, Volume 8 Nomor 2, ISSN : 2442-4943.

Mardi. (2011). Sistem Informasi Akuntansi. Bogor: Ghalia Indonesia.

M.Shalahuddin dan Rosa A.S (2014). Rekayasa Perangkat Lunak Terstruktur dan Berorientasi Objek. Bandung: Informatika Bandung.

Nugroho, Bunafit. (2013). Dasar Pemrograman Web PHP-MySQL dengan Dreamweaver Studi Kasus: Sistem Penerimaan Siswa Baru (PSB) Online. Yogyakarta: Gava Media.

Putri, Nenzy Ahlung Arniyanto dan Anggit Dwi Hartanto. (2013). Sistem Informasi Pengolahan Nilai Raport Pada Siswa SMP Negeri 1 Yogyakarta Berbasis
Web. ISSN 1411-3201 No. 4 Vol. 14. Halaman 38-43.

Raharjo, Budi. (2011). Membuat Database Menggunakan MySQL. Bandung: Informatika.

Riyanto. (2010). Membuat Sendiri Aplikasi Mobile GIS Flatform Java ME, Blackberry dan Android. Yogyakarta: Andi.

Sibero, C Ivan. (2010). Membuat Game 2D Menggunakan Game Maker. Yogyakarta: MediaKom

Sitorus Lamhot. (2015). Algoritma dan Pemrograman. Yogyakarta: CV. ANDI OFFSET.

Sri Dewi Anggadini dan Lilis Puspitawati.(2014).Sistem Informasi Akuntansi. Yogyakarta: Graha Ilmu.

Subagia Anton. (2016). Membuat web dengan PHP 7 dan Database PDO MySQLi Jakarta: PT Elex Media Komputindo.

Sujarweni, Wiratna. (2015). Sistem Akuntansi. Yogyakarta: Pustaka Baru.

Sutanta, Edhy. (2011). Basis Data dalam Tinjauan Konseptual. Yogyakarta. Andi.

Sutarman. (2012). Buku Pengantar Teknologi Informasi. Jakarta: Bumi Aksara.

Triaswati, Gesang. (2012). Sistem Komputerisasi Penggajian Guru Pada Sekolah Menengah Pertama 2 Sambungmacan berbasis Visual Basic 06. Journal Speed, Volume 4 Nomor 2, ISSN : 1979-9330.

Waluyo. (2011). Perpajakan Indonesia Edisi 10.Jakarta: Salemba Empat.

Yakub. (2012). Pengantar Sistem Informasi. Yogyakarta: CV Graha Ilmu.

Undang- Undang Nomor 13 tahun 2003 tentang ketenagakerjaan. 
Undang- Undang Nomor 36 tahun 2008 tentang pajak penghasilan.

Peraturan Direktur Jenderal Pajak No. PER16/PJ/2016, Peraturan Menteri Keuangan yaitu PMK No. 101/PMK.010/2016 dan PMK No. 102/PMK.010/2016 tentang tarif PTKP terbaru. 